\title{
Bara NDIAYE
}

Uniwersytet Warmińsko-Mazurski, Olsztyn

\section{Ewolucja pejzażu audiowizualnego we Francji}

$\mathrm{P}_{\mathrm{n}}^{\mathrm{r}}$ roblemy mediów we Francji w ogóle, a telewizji w szczególności, stanowiły i stanowią nadal ważny element życia publicznego. Kontrola informacji audiowizualnej stała się strategicznym celem dla większości rządów, zarówno IV, jak i V Republiki. Zdaniem Pierra Alberta: „En réalité, la France n'a pas réussi à régler le problème du statut des moyens audiovisuels alors qu'aux Etats-Unis; en Allemagne et Grande Bretagne, les principes et les réformes du régime de la radiodiffusion comme de la télévision ont, malgré la vigueur des débats qu'ils ont provoqués; été rapidement et facilement approuvés"1.

Droga ukształtowania się „francuskiego pejzażu audiowizualnego” („Paysage français audiovisuel” - PAF) była długa i skomplikowana. Pierwsza regularna emisja telewizyjna została zapoczątkowana w roku 1937, jednakże poszukiwania mające na celu stworzenie statutu telewizji w latach powojennych oraz monopol państwowy wyraźnie wpływały na jej stabilność. Ustawy z dnia 23 października oraz 30 grudnia 1944 roku utrzymywały zasady nacjonalizacji. Powstała sytuacja miała jednak znamiona tymczasowości i braku stabilności, w związku z czym pojawiły się żądania stworzenia prawdziwego statutu. Jednakże od roku 1946 aż do 1958 żaden z ponad szesnastu projektów i propozycji ustaw nie został zaakceptowany, nadal pozostawano w sytuacji niejasności i rozwiązań tymczasowych, którymi zadawalały się kolejne rządy, tym bardziej, iż taka rzeczywistość pozwalała im lepiej kontrolować cały system.

1 ,[... [ rzeczywiście Francji nie udało się uregulować problemu statutu środków audiowizualnych, podczas gdy w Stanach Zjednoczonych, w Niemczech i w Wielkiej Brytanii zasady i reformy reżimu radia i telewizji były szybko i łatwo zatwierdzone wbrew toczącym się dyskusjom" - tłum B. Ndiaye [w przypadku pozostałych cytatów, pochodzących ze źródeł francuskich, w przypisach podaje się warianty w polskiej wersji językowej w thumaczeniu autora]. Zob. źródło: P. Albert, Les médias dans le monde, Paris 1994, s. 107. 
W 1944 roku została utworzona RTF (Radiotélévision Française). Towarzyszące temu wydarzeniu dyskusje, dotyczyły problemu, czy RTF powinna pozostawać administracją, czy raczej przedsiębiorstwem? Zdaniem niektórych obywateli RTF powinna pełnić rolę jedynie serwisu publicznego. Dla innych, radio i telewizja były mediami, podobnie jak inne, dlatego też mogły i powinny być kierowane przez stronę prywatną. Opowiadający się za pierwszym wariantem utrzymywali, iż radio i telewizja mają swoją specyfikę i nie można porównywać ich z innymi rodzajami środków masowego przekazu. Kwestią, która wyróżnia je w sposób zasadniczy pozostaje między innymi fakt ograniczonej dostępności do fal Hertza, a zatem to państwo powinno być ich właścicielem. Zwolennicy monopolu podkreślali z kolei aspekty społeczne i polityczne, jako że telewizja była nowym rodzajem mediów, który jako pierwszy naruszał intymność ludzi. Rodziło to wiele pytań o charakterze organizacyjnym, strukturalnym, ale także w sferze moralnej, estetycznej, społecznej itp. Podejmowano pierwsze próby odpowiedzi na kwestie zasadnicze, w tym między innymi: Kto będzie decydował o programach, czy też co można było i należało proponować społeczeństwu?

W takich okolicznościach zdecydowano o ustanowieniu monopolu; monopolu związanego także z określoną rzeczywistością społeczno-polityczną okresu II wojny światowej. Między rokiem 1940 i 1944 radio pełniło rolę przede wszystkim swoistych wektorów propagandy niemieckiej, ale także i ruchu oporu (np. słynna „Odezwa do obywateli Londynu z dnia 18 czerwca").

Legislatorzy podkreślali, że radio i telewizja są środkami o niezwykłej sile oddziaływania na opinię społeczną, których nie wolno było w związku z powyższym oddawać w ręce prywatne. Monopol utrzymywał się do roku 1981. Problem, który zaistniał był zatem związany z koniecznością pogodzenia monopolu państwowego z zasadami pluralizmu politycznego, a także z zachowaniem zasad wolności i niezależności, niezbędnych w warunkach demokracji.

Z kolei dla V Republiki, tj. okresu personalizacji władzy, firmowanego przez silną osobowość generała De Gaulle’a, wobec trudności w odnalezieniu z prasą kompromisu właściwego (modus vivendi), charakterystycznym pozostaje fakt, iż to właśnie radiu i telewizji poświęcano najwięcej uwagi. Posługiwanie się telewizją stało się niezbędnym elementem w procesie komunikowania się ze społeczeństwem. Nowy reżim miał szybko zakończyć z sytuacją niepewności. 4 lutego 1959 roku Ustawa nadała RTF status przemysłowego i handlowego zakładu publicznego, $\mathrm{z}$ autonomicz- 
nym budżetem, pod auspicjami ministra informacji. W konsekwencji personel stracił status instytucji wypełniającej funkcje publiczne. Dyrektor był nominowany przez rząd i podlegał Radzie Nadzorczej. Powstanie tegoż statutu w październiku 1959 roku wprowadziło określone zmiany porządkowe. Jednak statut ten poddany został ostrej krytyce za jego autorytatywność. W rezultacie został zreformowany przez Alaina Peyrefitte, ministra informacji Francji w latach 1962-1966.

W oparciu o nowy statut $\mathrm{z}$ dniem 26 czerwca 1964 roku utworzono ORTF (L'Office de Radiodiffusion Télévision Française). Zatem ORTF nie pozostawał już pod autorytatywnym wpływem, ale pod opieką ministra informacji, którym w rządzie Generała De Gaulle’a był Alain Peyrefitte. A. Peyrefitte stał na stanowisku, że ORTF należało dać więcej autonomiczności. W tym celu powołał Radę Administracji (początkowo składająceą się z szesnastu, a w okresie późniejszym z dwudziestu czterech członków, nominowanych na okres trzech lat przez rząd albo Parlament). Powyższa Rada miała kontrolować obiektywizm informacji. Jednak dyrektor generalny nie był wybierany przez Radę Administracji, ale nominowany przez Radę Ministrów. Ciagłość jego mandatu nie była jednak określona, mógł być pozbawiony tej funkcji w dowolnym momencie. Druga forma ograniczenia dotyczyła sfery planu finansowego, Ministerstwo Finansów nie wyraziło zgody na formalną autonomiczność finansów Rady Administracji.

Działalność tegoż ORTF charakteryzowały napięcia polityczne. Rząd dążył do pełnej kontroli informacji, zwłaszcza w związku z wojną algierską. Wprawdzie w maju 1962 roku wojna zakończyła się, pojawiły się jednak kolejne powody, aby mieć telewizję pod kontrolą, były nimi wybory prezydenckie 1965 roku. Nowością owej kampanii wyborczej było to, że Francuzi mieli okazję ujrzenia w TV oponenta Generała De Gaulle'a (François Mitterand), zapoczątkowano emisję debat politycznych. To był właśnie ten moment, gdy TV zaczęła odgrywać ważną rolę w życiu politycznym.

Rozległość działań ORTF, który kontrolował wszelką produkcję audiowizualną we Francji, stwarzał trudności w faktycznym kierowaniu nim, w związku z czym pojawiły się propozycje jego dyslokacji, tak aby stworzyć możliwości sprywatyzowania co najmniej jednego kanału telewizyjnego.

Wydarzenia z maja 1968 roku wstrząsnęły ORTF, a on sam w tym okresie stał się obiektem ostrej krytyki i wewnętrznych agitacji. Pierwszym wyrazem pogłębiającego się kryzysu był spektakularny strajk 1968 
roku (maj-lipiec). Zasadniczą przyczyną tego strajku był właśnie problem w zakresie samego systemu informacyjnego. TV chciała przekazywać relacje z wystapień ruchu studenckiego, ale prezentacja była cenzurowana, wobec czego niezadowoleni dziennikarze podjęli strajk. W sytuacji, gdy Rada Administracji nie podejmowała żadnych działań, zasadniczym postulatem owej rewindykacji było utworzenie komitetu w celu zapewnienia obiektywności informacji.

W 1971 roku wybuchały kolejne skandale związane z nielegalną reklamą, czyli z ukrytą reklamą w telewizji. Tutaj jednak należałoby przypomnieć, iż reklama danej „marki”, czyli produktów wysokiej jakości, była akceptowana w telewizji dopiero od 1 października 1968 roku. Reklama podlegała wówczas kontroli Urzędu ds. Reklamy we Francji.

Valery-Giscard-d'Estaing, po przyjściu do władzy, starał się nadać wizerunek nowoczesności systemowi informacyjnemu. W rezultacie doprowadził do podziału ORTF (ustawa z dnia 7 sierpnia 1974 roku). Od 1 stycznia 1975 roku rozdzielono serwisy radia i telewizji na siedem stowarzyszeń autonomicznych, funkcjonujących bez żadnego organu koordynującego.

\section{Trzy pierwsze dotyczyły serwisów:}

- la société Télédiffusion de France (T.D.F.) - zajmowało się utrzymywaniem i rozwojem infrastruktury technicznej;

- la Société Française de Production (S.F.P.) - zajmowało się produkcją emisji na dużą skalę;

- l'Institut National de l'Audiovisuel (I.N.A.) - zajmowało się badaniami, archiwami i formacją zawodową.

Cztery kolejne miały charakter stowarzyszeń produkcji programów:

- Radio France,

- TF1, kanał pierwszy,

- Antenne 2, kanał drugi od 1964 roku, obecnie F2,

- FR3 (France-region), kanał trzeci, od 1973 roku.

Polityka programów ORTF i późniejszych stowarzyszeń niezależnych wywoływała wiele polemik. „La politique des programmes de l'ORTF, puis des sociétés indépendantes, a suscité bien des polémiques; on ne sut jamais avant 1974 accepter la concurrence entre les deux chaine. Pour la $3^{\text {ème }}$ chaine, (sa vocation cinéma et régions) fut plus facile à déterminer."

2 „Nigdy przed 1974 ORTF nie akceptował konkurencji między dwoma kanałami. Powołując kanał trzeci było łatwiej określić jego sferę działalności (kino, regiony)". Zob. P. Albert, Les médias dans le monde, Paris 1994, s. 113. 
- odnotowuje Pierre Albert. Właśnie w tym okresie biorą swój początek: autonomiczność, konkurencja i odpowiedzialność w ,pejzażu audiowizualnym Francji” (PAF). Rozpoczęła się walka o oglądalność, jej wzrost oznaczał większe pieniądze. Sondaże przybierały formę codzienną i coraz bardziej ulepszaną. Kwestią zasadniczą stały się starania na rzecz kaptowania i utrzymania wysokiej oglądalności.

W latach osiemdziesiątych powstała nowa organizacja PAF, z dwoma sektorami: prywatnym i państwowym. Ewolucja miała dynamiczny, ale i łagodny charakter (4-5 lat). Na mocy Ustawy z dnia 29 lipca 1982 roku powstało „La Haute Autorité de la Communication Audiovisuelle” (,Wyższy Autorytet Komunikacji Audiowizualnej”). Państwo oddelegowywało do niego swoje władze. Do podstawowych funkcji tego organu należało nominowanie dyrektorów poszczególnych kanałów oraz wszystko to, co dotyczyło deontologii. Jednak w rzeczywistości „Wyższy Autorytet Komunikacji Audiowizualnej" nie dysponował faktyczną usankcjonowaną władzą, powszechnie kontestowano fakt, iż jego członkowie byli wyznaczani przez władzę polityczną. Borykał się także z wieloma problemami z tytułu inicjatyw samego F. Mitterand'a, który samodzielnie podjął decyzję o utworzeniu telewizji prywatnych: Canal Plus (listopad 1984 roku), „La 5” (1985 rok), przyznania koncesji „Fininvest” (Berlusconi 40\%) i „M6” (dominanta muzyczna). Wszystko to wywołało wiele skandali, dodatkowo także nie były jasne warunki finansowe i regulaminowe.

W 1986 roku do władzy doszły nowe siły polityczne z Jacques’em Chirakiem jako premierem, które zdecydowały się odrzucić „system utworzony pospiesznie" przez rząd Laurant'a Fabius'a. Ustawa z dnia 30 września 1986 roku, dotycząca wolności komunikacji audiowizualnej, zmieniała tę z dnia 29 lipca 1982 roku. Monopol został zlikwidowany, ale w warunkach nowej rzeczywistości wolności komunikacji audiowizualnej nadal utrzymywano skomplikowany regulamin.

10 listopada 1986 roku została utworzona Państwowa Komisja Komunikacji i Wolności („Commission Nationale de la Communication et des Libertés" - C.N.C.L.). Składała się ona z trzynastu członków, nominowanych na dziewięć lat. Jej kompetencje były o wiele szersze, niż to miało miejsce w przypadku "Wyższego Autorytetu Audiowizualnego”, a budżet dziesięciokrotnie wyższy.

Wśród wielu funkcji C.N.C.L. można wyróżnić następujące: - nominowanie prezydentów kanałów publicznych oraz prezydenta I.N.A i 1/3 jego Rady Administracji, 
- wydawanie różnego typu autoryzacji emisji (na okres pięciu lat dla stacji radiowych oraz na okres dwunastu lat dla stacji telewizyjnych),

- dokonywanie wyboru stowarzyszeń, którym oddawano kanały komercyjne i określanie ich obowiązków,

- pełnienie roli konsultatywnej wobec wszystkich decyzji dotyczących komunikacji,

- kontrolowanie poszanowania regulaminów i kodeksu obowiązków,

- prezentowanie corocznych raportów.

Gabinet Chirac'a, po zmianie w grudniu wszystkich prezydentów kanałów publicznych, szybko unieważnił koncesje 5 kanału i M6. C.N.C.L. ponownie oddała ich nowym koncesjonerom. A w marcu 1987 roku podjęto decyzję o sprywatyzowaniu jednego kanału telewizji publicznej. Przez pewien czas wahano się między FR3, A2 i TF1, jako ostatnia przeszła w ręce nowych właścicieli TF1 (kwiecień 1987 roku).

„Pour la première fois dans le monde, un gouvernement a vendu, pour la privatiser, une chaîne du service public florissante. Le choix s'est porté sur TF1, alors qu'on pensait plutôt à A2 ou FR3."3 - pisze P. Albert. Właśnie owa prywatyzacja wywołała wiele debat, jako że TF1 był tym kanałem państwowym, który funkcjonował najlepiej. Wśród kandydatów na jego wykup znalazły się dwie grupy, wybierane z uwzględnieniem określonych kompetencji. Grupy te miały pokrywać 50\% kwot, zaś druga część kapitału była oddana publiczności (40\%) i pracownikom (10\%). Przy czym nadmieńmy, iż 50\% stanowiło niebagatelną kwotę trzech miliardów franków. Grupa Bouygues (ze wzrostem obrotów 25,5 milionów franków w 1986 roku) prezentowała się w sposób następujący:

$\begin{array}{lc}\text { Bouygues SA } & 25 \% \\ \text { Maxwell (1) } & 12 \% \\ \text { GMF } & 3 \% \\ \text { Editions Mondiales } & 2 \% \\ \text { Bernard Tapie } & 1,6 \% \\ \text { Financière Faltas (Worms) } & 1,5 \% \\ \text { Société Générale } & 2 \% \\ \text { Indo-Suez } & 1,2 \% \\ \text { Credit Lyonnais } & 1 \%\end{array}$

3 „Po raz pierwszy na świecie rząd sprzedał, żeby prywatyzować dobrze prosperujący kanał serwisu publicznego. Wybór padł na TF1, kiedy myślano raczej o A2 lub FR3”. Zob. P. Albert, Les médias dans le monde, Paris 1994, s. 129. 
Autres, dont

$0,7 \%$

Le Point, Marie-Claire,

Gallimard, Fleurus, etc...

Lącznie

$\mathbf{5 0 \%}$

1) Grupa Maxwell została w 1991 roku zamieniona przez Credit Lyonnais.

Źródło: P. Albert, Les Médias dans le monde, Paris 1994.

Reelekcja F. Miterrand'a w maju 1988 roku oraz powrót lewicy jako większości spowodowały kolejne zmiany w PAF. Tym razem nie kwestionowano układu z 1986 roku. Nie powrócono do prywatyzacji, pozostawiono przywileje, zagwarantowane przez prawo, natomiast zlikwidowano C.N.C.L i utworzono C.S.A. (Ustawa z dnia 17 stycznia 1989 roku), czyli Najwyższą Radę Audiowizualną, która do dziś reguluje działalność PAF. W jej skład wchodzi dziewięciu członków nominowanych przez Prezydenta Republiki, Prezydenta Zgromadzenia Państwowego i Prezydenta Senatu na okres dziewięciu lat. CSA pełni te same funkcje, jakie miał C.N.C.L, jednak zakres jej władzy jest zdecydowanie szerszy. Posiada w swoich uprawnieniach stosowanie sankcji (np. zawieszenia autoryzacji, karania grzywną itd.), przy czym bez prawa odwoływania Rady Państwowej.

Dla lat osiemdziesiątych XX wieku charakterystycznym pozostaje fakt, iż system prywatny i państwowy narodziły się właśnie w tym okresie, nawet jeśli towarzyszyło im wiele niepewności i wahań, związanych ze zmianami politycznymi. Wszyscy byli zgodni co do tego, iż zasady równowagi informacji, deontologia oraz reguły powinny być oddane organowi, który pełniłby rolę swoistej osłony między Państwem a Mediami. Realizm ekonomiczny i uznanie przez polityków faktu, iż informacyjne środki audiowizualne nie były tylko stawką ideologiczną i polityczną, ale także ekonomiczną, uświadamiał, iż i trzeba było wyjść poza granice państwowe, doprowadzić do rozszerzenia w Europie i na rynku międzynarodowym. Dwa czynniki wpływały na ten proces w stopniu zasadniczym, pierwszy, faktor techniczny - satelity, drugi - czynnik kulturalny.

Regulacje objęły ewolucje ekonomiczne i techniczne. Legislator określił reguły dyfuzji: rodzaje emisji, reklamy, filmów... Należało zachować zasadę oryginalności twórczości, $60 \%$ powinna stanowić produkcja europejska, a i wśród tych $60 \%, 40 \%$ powinno być pochodzenia francuskiego. Określono najbardziej korzystny czas z przeznaczeniem na pokazy niektórych filmów dokumentalnych o charakterze kulturalnym. Regulamin 
określał także warunki emisji filmów, kwoty roczne, a nawet dni, w jakie można było je pokazywać. Trzeci zakres obowiązków dotyczył reklam, ilości minut w każdej godzinie. Niektórych towarów i produktów, jak na przykład alkoholu, papierosów nie wolno było reklamować w ogóle. Pozostając pod kontrolą CSA, telewizje wypełniały wszystkie te obowiązki do początku lat dziewięćdziesiątych, jako że do tego czasu kanały telewizji satelitarnej i kablowej nie były jeszcze zbyt dobrze rozwinięte.

Obecnie PAF, oprócz radia i innych serwisów, składa się z sektora publicznego, do którego należą France Télévisions z dwoma kanałami F2 i F3, ARTE, TV5 i Canal France International. Trzeba także odnotować mnożenie kanałów tematycznych i lokalnych (ponad 180) sieci kablowych lub satelitarnych. Przy czym France Télévisions, z jej dwoma kanałami, osiągała mniej niż 40\% oglądalności, podczas gdy TF1 sama przyciagała znacznie więcej. To, zdaniem P. Alberta, wyróżnia Francję wśród innych krajów europejskich: „La situation du service public français diffère notablement de celle de nos grands voisins: en Angleterre, la $\mathrm{BBC}$ ne reçcoit pas de publicité, ses deux chaînes sont complémentaires et ont une vocation nationale. En Italie, la RAI contrôle trois chaînes dont une régionalisée ; de même en Allemagne avec les trois chaînes ZDF, ARD et ARD3 ; dans ces deux pays aussi, la part des recettes de publicité est limitée",

ARTE, na mocy porozumienia Mitterand - Kohl w grudniu 1988 roku zdecydowano o utworzeniu kanału kulturalnego francusko-niemieckiego. Autonomiczny kanał od września 1992 roku powstał na miejsce byłego kanału 5. Współkierowany przez Arte Niemiec (Asosiacja ARD i ZDF) i 7-ARTE Francja z siedzibą w Strasburgu.

Trzeba powiedzieć także, że France Télévisions bierze udział w konsorcjum Euronews, programach informacyjnych „,non stop” za pośrednictwem systemów satelitarnych i drogą telewizji kablowej (od stycznia 1993 roku, Centrum w Lyonie).

4 „Sytuacja francuskiego serwisu publicznego różni się znacznie od tej, która ma miejsce u naszych sąsiadów: w Anglii, BBC nie nadaje reklam, jej dwa kanały pozostają prawdziwie komplementarnymi i pełnią funkcje państwowe. We Włoszech, RAI kontroluje trzy kanały, wśród których jeden ma charakter regionalny, podobnie jest w Niemczech w przypadku trzech kanałów ZDF, ARD1 i ARD3. W tych dwóch krajach zyski z tytułu nadawanych reklam są ograniczone”. Zob. P. Albert, Les médias dans le monde, Paris 1994, s. 125. 
TV5, od 1984 roku, program frankofoniczny via satelity, pokazywany w ponad stu krajach Europy, Ameryki, Afryki i Azji. Na jego programy składają się emisje selekcjonowane z France Télévisions, TF1, RTBF (Belgia), TSSR (Szwajcaria) i telewizji Kwebek.

Canal France International (Międzynarodowy), bank zdjęć, proponowanych telewizjom frankofonicznym Afryki i Trzeciego Świata.

Trzeba podkreślić, iż rodzi się wiele pytań, dotyczących sektora publicznego. Jakie powinien podejmować działania sektor państwowy w sytuacji konkurencji? Czy należy zmniejszać reklamę i zwiększać opłatę i dotacje? Niektórzy opowiadają się wręcz za odwoływaniem reklam z telewizji publicznej. Ustawa Trauman'a z sierpnia 2000 roku ograniczała reklamę w telewizji publicznej z dwunastu do ośmiu minut w ciągu godziny.

\section{Sektor komercyjny składa się z:}

Canal Plus, od 1984 roku, Canal + stanowił pierwszą wyrwę w monolitycznym systemie państwowej telewizji francuskiej. Telewizja płatna, dzisiaj bardzo popularna, zwłaszcza w dziedzinie programów rozrywkowych (filmu). „Dziesięć lat po powstaniu Canal Plus miał już około 4 milionów abonentów we Francji i około 6 milionów abonentów za granicą" 5 . Udziałowcami Canal Plus byli: Public Canal Plus, Credit commercial de France, PNB, pracownicy Canal Plus, Caisse des dépôts, Compagnie générale des eaux, Havas.

Wielkim sukcesem Canal Plus jest znaczący udział w internacjonalizacji telewizji europejskiej. Canal ma swoją reprezentację we Włoszech, Niemczech, Hiszpanii, Belgii, Polsce i w krajach afrykańskich (Canal Horizon). Ciągle podejmuje starania o możliwości dalszej ekspansji, rywalizując skutecznie z potęgami amerykańskimi i niemieckimi. Canal wykorzystuje w tej walce wszelkie zdobycze nowoczesnej techniki włącznie z satelitą Astra.

M6, to kolejna prywatna telewizja, utworzona w 1986 roku na podstawie koncesji państwowej udzielonej kilku udziałowcom: Publicis (25\%), Gaumont (25\%), NRJ (18\%), pracownicy (10\%). M6 nadaje programy s. 103.

5 B. Golka, Wybrane zagraniczne systemy informacji masowej, Warszawa 1997, 
rozrywkowe, filmy, muzykę, a także informacyjne przez dwadzieścia cztery godziny na dobę.

La Cinquieme - powstała w 1994 roku, utworzona przez kilka grup przy udziale kapitału państwowego w wysokości pięćdziesięciu jeden procent. Służy głównie informowaniu o sprawach polityki społecznej, rynku pracy itp.

TF1 należy do najpopularniejszych telewizji we Francji. Od 15 kwietnia 1987 roku pozostawała w rękach F. Bouygues, któremu udało się ściagnąć wiele gwiazd telewizji (Anne Sinclair, Christine Okrent, Michelle Cotta, Etienne Mougeotte...). F Bouygues był prezydentem do 12 października 1988 roku, po czym przekazał swoje kompetencje swojemu synowi Martinowi i swojej prawej ręce Patrickowi Le Lay. TF1 łatwo wygrywała walkę z 5. Oglądalność regularnie wzrastała i już w 1988 roku osiągnęła ponad 40\%. W 1992 roku TF1 zmieniła siedzibę, z ulicy Cognac-Jay przeszła do budynku w Boulogne nad Sekwaną. Nastąpił wzrost obrotów z 3,9 miliardów franków w 1987 roku, do 4,7 w 1989 roku, 6,5 w 1991 roku i 7,3 w 1992 roku, zysk wyniósł 500 milionów. Przy czym wartym podkreślenia jest fakt, iż w 1992 roku wzrost całości obrotów Bouyges wyniósł 62 miliardy franków, zatem działalność TF1 miała dla niego relatywnie marginalny charakter.

Dzisiaj, jak podaje „Le Monde”: „TF1 est la rente audiovisuelle du groupe Bouygues. La filiale médias du géant du BTP a enregistré en 2003 un résultat de 191,5 millions d'euros, en forte hausse (23,4\% pour un chiffre d'affaires de 2,7 milliards d'euro). Malgré l'érosion de son audience, la première chaîne privée française parvient à capter plus de la moitié des recettes publicitaires télévisuelles"6.

Według pana Le Lay, dyrektora generalnego grupy TF1 receptę na sukces można zawrzeć w jednym zdaniu, wypowiedzianym przez Francisa Bouygues'a w momencie wykupu kanału: „Avec Bouygues, la Une restera la Une. «En clair, le fondateur du groupe numéro mondial de BTP imposait comme principe premier de conserver la place de numéro un dans l'au-

6 „TF1, jako dochód audiowizualny grupy Bouygues. Filial medias giganta BTP (budownictwo i prace publiczne), rejestrował w 2003 wynik 191,5 milionów euro, (23,4\%, wzrost obrotów, 2,7 miliarda euro). Wbrew erozji jej oglądalności, pierwszy kanał prywatny francuski dąży do tego, aby kaptować ponad połowę wpływów z reklam telewizyjnych”. Zob. „Le Monde”, 25.02.04. 
diovisuel français». «Il fallait conforter la position de leader de la chaîne»"”7 - przypomina Etienne Mougeote, vice-prezydent TF1.

Wygląda na to, że ani wzrost ilości satelitów, ani pojawienie się nowych zwyczajów konsumpcji telewizji nie hamują rozwoju TF1. Potwierdzają to oficjalne statystyki: „En 2003 TF1 a encore obtenu 31,5\% de parts d'audience. France 2, à la seconde place, est à plus de 10 points en arrière, avec $20,5 \%$. Les deux chaîness affichaient des taux d'audience comparables en 1987 , avec environ $35 \%$ chacune" ${ }^{\text {. }}$.

Szesnaście lat po prywatyzacji TF1 pozostaje tym kanałem, który dominuje w PAF. TF1 korzysta z pozycji niezwykłej w Europie. Pomimo tego, iż oglądalność maleje wraz z pojawieniem się nowych kanałów telewizyjnych we Francji, ciągle udaje się jej osiągać ponad połowę inwestycji reklamowych w telewizji. „En 2003, TF1 devrait ainsi encore capter près de $55 \%$ de parts du marché publicitaire" ${ }^{9}$ - konstatuje jeden $\mathrm{z}$ analityków - specjalistów ds. mediów.

Żeby osiagnąć ten cel, TF1 postawił na potrzeby i oczekiwania dużej rzeszy widzów. W nadawanych programach kanał oddaje pierwszeństwo na rzecz piłki nożnej, programów rozrywkowych, telenoweli. „Nous sommes une télévision de la demande et non une télévision de l'offre. TF1 s'efforce d'être toujours à la recherche de ce qui peut plaire au plus grand nombre.” - podkreślała M. Mougeotte - („Jesteśmy telewizją popytu, a nie telewizją podaży. TF1 stara się zawsze pokazywać to, co może podobać się możliwie największej rzeszy ludności” - „Le Monde”, 25.02.2004).

Jednak obrany kierunek naprowadził TF1 ku pewnym dryfom. Na przykład w 1991 roku Patrick Poivre D’Arvor (PPDA), prezenter głównego wydania wiadomości o godz. 20, gwiazda TF1, ,papież wieczornej mszy", jak o nim mówią w TV, wymyślił wywiad z Fidelem Castro, prezydentem Kuby. To był jeden z największych skandali francuskich mediów ostatnich lat.

7 „Pierwszy kanał zostaje Pierwszym kanałem”, jasne, że założyciel grupy BTP numer dwa w świecie narzucił jako zasadę naczelną utrzymanie pierwszego miejsca we francuskim systemie audiowizualnym. Trzeba było wzmacniać pozycję leadera kanału".

8 „W 2003 roku, TF1 uzyskał wyniki: 31,5\% oglądalności i 54\% rynku reklamowego Francji. France 2, na drugim miejscu, był o 10 punktów niższy, z 20,5\%. Te dwa kanały miały porównywalne poziomy oglądalności w 1987 roku, około 35\% każdy". Zob. „Le Monde”, 25.02.04.

9 „W 2003, TF1 kaptowała jeszcze około 55\% kwot rynku reklamy. To prawdziwa wzorowość modelu TF1. Zob. „Le Monde”, 25.02.04. 
Kolejnym był epizod związany z reality - tv. Gdy M6 zaczęła emisję „Loft Story” dyrektor generalny TF1, jako głos reprezentatywnego kanału rodziny francuskiej, podkreślał, że „nie wolno wszystkiego pokazywać w telewizji”. Ileś tygodni później, po niebywałym sukcesie pierwszej emisji reality - tv we Francji, TF1 podpisywała umowę pięcioletnią z Endemol, producentem „Loft Story”. Ale te przeszkody zaledwie zarysowały wizerunek, w jeszcze mniejszym stopniu zaszkodziły ogólnemu modelowi.

Działalność, związana z różnorodnymi operacjami, które TF1 praktykuje od wielu lat, daje teraz 43,7\% wzrost obrotu grupy. Wśród nich są kanał LCI, Eurosport, bukiet TPS (telewizji satelitarnej, kanał młodzieżowy TF6 ). Oprócz tego TF1 rozwija także sprzedaż płyt, książek, gadżetów „oglądanych w telewizji”. Dodatkowe dochody pojawiają się np. w związku z wykorzystaniem SMS-ów podczas niektórych emisji telewizyjnych. „L'effet de levier est impressionnant. [...] Il y a peut d'exemples de groupes réalisant une telle marge." - podkreśla Edouard Tetreau, analityk finansowy Kreditu Lyonais. - („Efekt dźwigni jest imponujący [...]. Istnieje niewiele grup, realizujących takie zyski.” - „Le Monde”, 25.02.04).

Obecnie głównymi akcjonariuszami TF1 są Bouygues (41,2\%), pracownicy $(3,7 \%)$ i Société générale $(1,5 \%)$.

TF1, grupa w której znajduje zatrudnienie 3480 ludzi, wśród których 470 to dziennikarze, stara się utrzymywać pierwszeństwo wobec innych kanałów francuskich. Ale, jak długo może on jeszcze pozostawać wyjątkiem ekonomicznym w europejskim pejzażu audiowizualnym, gdzie zmiany technologiczne są tak znaczące? W tej sytuacji, według analityków, misja wyznaczona France 2 konkurowania z TF1 nie jest możliwa. Zaś wydarzenia z 3 lutego w redakcji F2 wydają się realnym potwierdzeniem tej tezy.

Właśnie we wtorek trzeciego lutego 2004 roku, w głównym wydaniu wiadomości o dwudziestej na TF1, Alain Juppé, prezydent Bordeaux, jeden z możliwych następców Chiraca, zakomunikował: „Mardi 3 février, le 20 heures de TF1 au cours duquel Alain Juppé a annoncé qu'il ne renoncé pas à la politique; malgré sa condamnation, a été suivi par 11,9 millions de téléspectateurs. A la même heure, 5,17 millions de personnes ayant choisi le journal de France 2 ont entendu David Pujadas expliquer que Juppé se retirait de la vie politique" ${ }^{\text {"10 }}$. Jak widać błąd był poważny, ponieważ

10 „Mówił, że nie odmówi sobie życia politycznego niezależnie od wyroku. 11,9 milionów odbiorców oglądało to wydanie wiadomości, w tym samym czasie 5,17 milionów ludzi wybrało wiadomości F2 i słuchało Davida Pujadas, prezentera tego 
główny kanał serwisu publicznego ,francuskiego pejzażu audiowizualnego”, podając do publicznej wiadomości „niesprawdzoną sensację” nie wypełnił swojej podstawowej misji, aby informować prawdziwe. W następnym wydaniu 4 lutego David Pujadas przeprosił za niedokładną informację: „Nous avons commis une erreur d'interprétation des informations dont nous disposions. [...] Parler d'interruption de la carrière [d'Alain Juppé] était abusif, nous le regrettons et vous présentons nos excuses pour cette maladresse” - („Popełniliśmy błąd interpretacji informacji, którymi dysponowaliśmy. [...] Mówienie o zakończeniu kariery przez Alain'a Juppiego było błędne, żałujemy i przepraszamy za tę niezręczność.” - „Le Monde", 12.02.04)

Jednak, to był tylko wierzchołek góry lodowej. Olivier Mazerolle, dyrektor informacji F2, nie mógł dopuścić, aby Alain Juppe wybierał TF1 zamiast serwisu publicznego, zwracając się do Francuzów. Już podczas konferencji redakcyjnej o dziesiątej rano trzeciego lutego zwrócił się do dziennikarzy serwisu politycznego: „Nous ne sommes pas proches des hommes politiques, et voilà ce qui nous arrive. Il faut savoir leur dire bonjour, merci, au revoir et être poli avec eux" "11. W taki sposób wywołał największy kryzys redakcji F2 od wielu lat.

5 lutego br. agitacja wśród pracowników F2 przybrała najmocniejszą formę. Stowarzyszenie dziennikarzy zwołało zgromadzenie bez Olivier Mazerolle, podczas którego mówiono o „malaise”, „dysfonctionnements”, „l'incompréhension” et „le manque de dialogue” - („niepokoju”, „niefunkcjonowaniu”, „nierozumieniu” i ,braku dialogu” z szefami redakcji„Le Monde”, 29.02.04). Niektórzy wyrażali odmienne stanowisko od linii redakcyjnej dziennika F2. Podjęto decyzję o wotum nieufności. Postawiono dwa pytania: „Accordez-vous votre confiance au directeur de l'information ?" et „Accordez-vous toujours votre confiance à l'équipe du 20 heures?”. 69\% des réponses négatives („Czy ufacie dyrektorowi informacji?” i „Czy ufacie zespołowi głównego wydania wiadomości?” 69\% odpowiedzi było na „nie” - „Le Monde”, 12.02.04).

Prezenter D. Pujadas, który jest związany z tym kanałem od września 2001 roku, wycofał się na okres trzech tygodni z prezentacji wiadomości.

kanału, który tłumaczył, że Alain Juppé wycofa się z życiu politycznego”. Zob. „Le Monde", 12.02.04.

11 „My nie jesteśmy blisko polityków, i oto, co się dzieje z nami. Trzeba umieć mówić dzień dobry, dziękuję, do widzenia i być grzecznym wobec nich”. Zob. „Le Monde", 29.02.04. 
Olivier Mazerolle, dyrektor informacji F2, rezygnując ze swojej funkcji, deklarował, że „qu'il assumait pleinement cette faute [...] et que la rédaction devait continuer à travailler” (,bierze calą odpowiedzialność za ten błąd na siebie, a redakcja powinna kontynuować pracę” - „Le Monde”, 12.02.04).

Błąd, popełniony trzeciego lutego 2004 roku przez Pujadas i Mazerolle, a zwłaszcza pozostawanie $\mathrm{w}$ tym błędzie bez korekty, bez podania informacji o tym, że Juppé w tym samym czasie składa oświadczenie w TF1, jest zdaniem specjalistów ds. mediów francuskich, właśnie wynikiem równania infernalnego. „La vaine concurrence dans laquelle nous sommes engagés depuis des années avec TF1 nous conduit de plus en plus à faire des choix risqués [...]” - („Próżna (daremna) konkurencja, w którą jesteśmy zaangażowani przez lata w TF1, przywodzi nas coraz częściej do tego, aby dokonywać wyborów ryzykownych" - pisze przedstawiciel Stowarzyszenia Dziennikarzy - „Le Monde”, 12.02.04).

„Konkurencja transformuje się w denaturację informacji”, żałował Daniel Wolfromm, ze Stowarzyszenia Dziennikarzy F2. Trudno nie zgodzić się z opinią innego dziennikarza tegoż związku: „Il y a une réflexion à mener sur la rapidité de l'information. Aujourd'hui, avec le numérique, les rythmes se sont accélérés, on peut tout changer jusqu'au dernier moment, ça induit une certaine forme d'irresponsabilité.” („,Potrzebna jest refleksja nad szybkością informacji. Dziś w dobie telewizji cyfrowej, rytmy uległy przyspieszeniu, można zmieniać wszystko do ostatniego momentu, to prowadzi do pewnej formy braku odpowiedzialności” - „Le Monde”, 12.02.04).

Kryzys F2 jest o tyle poważny, że dotyczy jedynego bastionu kanału informacyjnego, produkowanego przez telewizję publiczną. Był to pierwszy przypadek, gdy kanał telewizyjny we Francji otrzymał tak groźne ostrzeżenie ze strony Najwyższej Rady Audiowizualnej (CSA). Właśnie 12 lutego CSA dała ostrzeżenie F2 za to, że na początku wiadomości o godzinie dwudziestej 3 lutego podano ,une information qui n'existait pas encore” et qui „,'est ensuite révélée fausse”, France 2 „n'as pas respecté son obligation de bonne information des téléspectateurs" - (,informację, której jeszcze nie było”, i która później „okazała się nieprawdziwa”, F2 „nie szanowała obowiązku podawania rzetelnej informacji teleodbiorcom" thumaczył CSA - „Le Monde”, 13.02.04).

CSA stosował wobec F2 najwyższy poziom ostrzeżenia. Joseph Daniel z CSA komentuje, że w 1991 roku kiedy PPDA, prezenter TF1, wmontował nieprawdziwy wywiad z Fidelem Castro, „Il n’y avait pas de 
mise en demeure, le CSA s'était contenté de constater les faits” („nie było żadnych ostrzeżeń, zobowiązań, CSA ograniczył się do konstatacji faktów” - „Le Monde”, 13.02.04).

$* * *$

Z powyższych wywodów wynika, że dotychczas antagonizm między prywatną i publiczną telewizją we Francji nigdy nie był tak silny. Ale powstanie naziemnej telewizji cyfrowej, która do 2006 roku ma udostępnić wielu milionom Francuzów dziesiątki nowych kanałów bezpłatnych, może stać się „,nową kością niezgody” między TF1 a France Télévisions.

\section{Summary}

Television in France has been a significant element of public life. A majority of governments in the $4^{\text {th }}$ and $5^{\text {th }}$ Republics aimed to control audiovisual information. Television was present even before WWII, yet it could not develop. After the war its progress was inhibited by the long-term monopoly of the state. As the political forces were changing, so were the organizations controlling television. Due to the reforms of the 1980's two sectors emerged in France: the state owned sector and the privately owned sector. At present the audiovisual landscape of France is made up of the public sector, incorporating French Television with channels F2 and F3, ARTE, TV5 and Canal France International, and a private sector with Canal Plus (Canal + since 1984), M6, La Cinquieme and TF1. Since its privatization of nearly twenty years ago, TF1 has been the leading channel. 